\title{
Critical Discourse Analysis of the Academic Discussion on Internationalization of Higher Education
}

\author{
Saule Anafiova ${ }^{1}$ \\ ${ }^{1}$ Faculty of Education and Psychology Eotvos Lorand University ELTE \\ *Corresponding author. Email: saule.anafinova@ppk.elte.hu
}

\begin{abstract}
The current paper applies the Critical Discourse Analysis in order to analyse the academic discussion on higher education internationalization at the Symposium Trends in International Higher Education and Regionalism at the Waseda University in 2008. The aim of the current paper is to uncover hidden meanings in the academic discussions of international experts on higher education internationalization. The analysis of the panellists' discussion reveals that the world is characterized by inequality between the rich and poor countries, education systems and universities. Despite the societal belief in the education as public good, it is subject to commercial trade today. From the analysis, we can see the clash of two ideologies "education as private good" and "education as public good". Many participants expressed negative evaluations of liberalism in education, suggesting that more emphasis should be put on cooperation than competition. In this discussion, we can observe a clash between supporters and opponents of liberal education policy. With issues of inequality between countries, education systems, universities and people, as well as issues of ethnic disagreements threatening the harmony of diversity, the world is perceived by speakers as much more complex as it seems at first.
\end{abstract}

Keywords: Higher education internationalization, Critical Discourse Analysis, Global competition.

\section{INTRODUCTION}

Most academic writers represent internationalization of higher education as an inevitable, though a very beneficial, process. Internationalization is assumed important, if universities want to be globally competitive [3]. The word "competition" is often used in connection with internationalization of higher education, as well as other words including "privatization" and "liberalization". Thus, the ideology of internationalization is offered to the public like the best dish in the restaurant menu.

The aim of the current paper is to uncover hidden meanings in the academic discussions of international experts on higher education internationalization. To achieve this goal, the researcher analyses the academic discussion on internationalization based on the scheme, offered by Fairclough [1] in the chapters 5 and 6 of his book "Language and Power". In addition, the researcher uses explanations in his book "Analysing discourse: Textual analysis for social research".
According to [2], he wrote the last book in order to analyse such themes as governance, globalization and others (p. 7).

The analysed text is a result of work of the First International Symposium on Asian Cooperation, Integration and Human Resources, which took place at the Waseda University from 17 to 18 January 2008. I got access to a published version of Session I of the Symposium - "Trends in International Higher Education and Regionalism" (2009). Four international higher education experts were speaking during the session. Their presentations were followed by a 30-minute moderated discussion, which was transcribed and published by the Waseda university. The researcher chose the Discussion part of the Session for my analysis. For the convenience of analysis, the researcher had to numerate the lines of the transcript. 


\subsection{Critical Discourse Analysis by Fairclough}

According to [2], language tools are used to create the discourse, structuring and influencing important policy debates. Thus, the tool of classification helps to construct "“particular visions" of the world" (p. 213). This is done through establishing relationships of equivalence and difference (p. 215) between words or phrases. Specifically, Fairclough [2] claims that classification shapes "how people think" (pp. 101102). He explains that relations of equivalence can be established between phrases through making them hyponyms of a general category, and then relations of difference can be established between "the lists of cohyponyms" [2, pp. 101-102].

According to (2001), although agents are usually animate, they can be realized as inanimate nouns, abstract nouns or nominalizations (as listed in p. 124). Passive voice is often used in order to avoid mentioning the agent (p. 125). Fairclough [2] characterizes nominalization as deprived of tense and modality (pp. 143-144). Nominalization [2] carries a general and abstract nature (p. 144). Furthermore, Fairclough [2] notes that narratives dedicated to the "global economy" extensively apply nominalization in order to represent global processes not with the use of verbs, but in form of entities (pp. 12-13). This helps to avoid mentioning the agents of processes, which leads to a lack of clearness about the responsible agents [2, pp. 12-13]. In simple words, processes are represented without agents so the reader does not know who the people are or what the organizations behind the processes are. According to [2], the same effect (as by nominalization) is produced by the use of "process nouns", for example, "progress" or "hope" (p. 132). Passive voice is also often used to hide the agent $[1, \mathrm{p}$. 125].

\subsection{The text and the interaction between the participants}

The text is ordinary by structure: it begins with greetings and short introductory word of the moderator and then is organized in Question-and-Answer type of discussion between the panellists and members of audience. The Discussion ends with final words of the moderator.

Fairclough [2] indicates several types of logical connectors: causal, conditional, temporal, additive, elaboration and contrastive or concessive (p. 89). There were two pieces in the text, which were more abundant in the use of logical connectors. Both pieces belong to the participants from the audience, who asked their question to the presenters in the beginning of discussion. Using the logical connectors, the authors of these two pieces managed to influence the flow of the whole discussion. We can say, that the people who asked questions to the panelists, played an active role in the discussion. The hidden purpose of both speakers was to draw attention of the panelists and the audience to the negative consequences of higher education internationalization. In the beginning of both pieces, CONTRASTIVE logical connectors are used in order to draw parallel with the ideas, which were pronounced in the speeches of presenters prior to the start of discussion. Further, the participants who asked the questions used ADDITIVE logical connectors and ELABORATION in order to explain their questions in more detail. Speakers also use logical connectors with a meaning of CONSEQUENCE in order to justify the significance of their questions.

While the atmosphere of the conference dictates formal environment, the degree of this formality seems to be not so high in comparison with the example of formal speech in a court by Fairclough [1]. The degree of slight informality of language signals to a reader about equal relations between the participants (including the moderator, presenters and members of audience), who recognize each other's authority and expertise to speak about the issues raised in the discussion. All the participants were moderately using the formal and less formal language during the discussion. The speakers used formal language only to greet the presenters and thank them for presentation. Although the speaker begins with a less formal word "hello" (18) instead of, for example, "good afternoon", he uses more formal phrases to greet the presenters ("I would like to begin by congratulating the panellists...).With exception to greetings and instructions (for example, lines 14-17) and specialized terms, many less formal phrases were found during discussion. For example, the moderator uses simple language to comment his actions.

The professor moderator did not interrupt the speakers or did not enforce explicitness, but he obviously controlled the topic of discussion [5, p. 135]. He did so by specifying the purpose of discussion in general (look lines 4-9) and by directing some questions to the speakers, who were more experienced to answer them (for example, lines 121-122). By doing so, he set certain expectations of the answers, which will be given by panellists. At the same time, people who asked questions also contributed to the development of the flow of discussion, as it was mentioned above. Grammatical questions were used to encouraging the other people to participate in the discussion.

But in the long-term, if you receive students from abroad and you have no means of offering them employment, then how can you rationalize the decision. (lines 62-64) 
"You" is used once and "we" is used several times. Based on Fairclough [2], we can quote him and say that the speaker assumes the power of prediction ( $\mathrm{p}$. 171), in which he speaks authoritatively about what should be done and calls for action. The speaker here speaks on behalf of community of educational researchers and policymakers, who often consult the researchers as experts and may be present at the audience. This "we" is inclusive by nature [2, p. 182].

[...] Because of the diversity we have to help the poor ones. (lines 46-47)

\section{FINDINGS}

\subsection{Experiential values}

The analysis of the panellists' discussion reveals that the world is characterized by inequality between the rich and poor countries, education systems and universities. Despite the societal belief in the education as public good, it is subject to commercial trade today. Classifications schemes, which can be found in the transcript of the discussion of panellists, can be drawn upon the division between the public nature of education and education as a form of commercial trade:

Table 1. Classification scheme 1 (number of lines indicated in brackets) ${ }^{1}$.

\begin{tabular}{|c|c|}
\hline $\begin{array}{l}\text { Education as public } \\
\text { good }\end{array}$ & $\begin{array}{l}\text { Education as private } \\
\text { good }\end{array}$ \\
\hline $\begin{array}{l}\text { The public goods } \\
\text { character of higher } \\
\text { education (p. 23) } \\
\text { The social character of } \\
\text { universities (p. 256) } \\
\text { Mutual understanding } \\
(28,41,61) \\
\text { Social higher education } \\
\text { (127) } \\
\text { Social dimension of } \\
\text { higher education (136, } \\
\text { 138) } \\
\text { Social issues (172) } \\
\text { Social needs (176) } \\
\text { International peace or } \\
\text { mutual understanding } \\
\text { (363) Cooperation models } \\
\text { (347) }\end{array}$ & $\begin{array}{l}\text { Exploiting the } \\
\text { commercial gains (22) } \\
\text { Brain drain (problem) } \\
(24,31,34) \\
\text { Economic benefits (60) } \\
\text { Human capital } \\
\text { educational gap (32) } \\
\text { Liberalize (142, 257) } \\
\text { Liberalized system } \\
\text { (178-179) } \\
\text { Private providers (146) } \\
\text { Private enterprises } \\
\text { (147) } \\
\text { Private universities } \\
\text { (148) } \\
\text { Private sector (313- } \\
314,318,320,323) \\
\text { Competition (167) } \\
\text { Competing (145) } \\
\text { Developing gap (169) } \\
\text { GATS (abbr.) (257) } \\
\text { Business models (346, } \\
\text { 347) }\end{array}$ \\
\hline
\end{tabular}

\footnotetext{
${ }^{1}$ Here and further numbers in brackets indicate lines, except where pages are shown as "p. X" or "pp. X".
}

A lot of the phrases from the two lists go in collocation with each other, where contrastive relations are established between the clauses with these phrases through the use of contrastive logical connectors or through putting sentences with contrastive meaning together (according to Fairclough [2], contrastive relations can also be established without a marker (p. 54)).

But, the issues that were raised in the presentations affirmed that the internationalization of higher education in the region is really exploiting the commercial gains, CONTRASTIVE instead of promoting the public goods character of higher education. (Lines 20-23)

Further, there was a classification of countries into developed and developing countries. While there were no clear contrastive relations between the clauses with the phrases from these two lists, these phrases were often used in collocation between each other. Nevertheless, we can see the concepts are clearly contrastive to each other (For example, lines 36-40, 74 -77). In addition, the classification was found between "top universities" and "bottom universities".

\subsection{Relational values}

In general, the speakers did not to avoid calling things by their names. However, it can be seen that speakers used some mild expressions to refer to some big international issues. For example, the phrase "gender parity" (87) sounds to me softer than a more widespread phrase "gender equality" although they have the same meanings. Similarly, another speaker used the phrase "issues or problems of divide and disparity" instead of saying "issues or problems of divide and inequality" (122). Probably, this was done to provide a more objective discussion of the problem and to avoid being emotional. I do not see any ideological or other hidden reasons for using softer words here.

\subsection{Expressive values}

The internationalization of higher education is perceived by speakers as having positive and negative sides, such as promoting "mutual understanding" (21) and "exploiting the commercial gains" (41).

\subsection{Experiential values of grammatical features}

The key statements can be grouped around two topics for easier analysis: 1) description of current situation (Table 4); 2) prediction of future situation and suggestions (Table 5). Most of processes are presented 
as events without responsible agents or as attributed states. Even in those statements, where processes are presented as events, we do not know the agent because researchers and higher education experts, the speakers can be included in the list of responsible agents.

Table 2. "Description of current situation" group. Analysis by type of process.

\begin{tabular}{|l|l|l|}
\hline No. & Statement & Type of process \\
\hline 1. & $\begin{array}{l}{[\ldots] \text { The internationalization of higher education in the region is really exploiting }} \\
\text { the commercial gains [...]. (Lines } 21-22)\end{array}$ & SVO (action) \\
\hline 2. & $\begin{array}{l}{[\ldots] \text { The internationalization of higher education in this region is a very effective }} \\
\text { tool for mutual understanding [...]. (Lines 27-28) }\end{array}$ & SVC (attribution) \\
\hline 3. & {$[\ldots]$ The quality of some universities has been decreasing [...]. (Lines 128-129) } & SV (event) \\
\hline 4. & $\begin{array}{l}\text { So, the European project, from a higher education point of view, has always been } \\
\text { in favor of social higher education. (Lines 126-127) }\end{array}$ & SVC (attribution) \\
\hline 5. & $\begin{array}{l}{[\ldots] \text { The Bologna process is not forcing European universities to liberalize. }} \\
\text { (Lines 140-142) }\end{array}$ & SVO (action) \\
\hline 6. & $\begin{array}{l}\text { If we look at the Asian reality, the market is really strong and the institutional } \\
\text { initiative is also very strong. (Lines 238-239) }\end{array}$ & $\begin{array}{l}\text { SVC; } \\
\text { (attribution) }\end{array}$ \\
\hline 7. & $\begin{array}{l}\text { Some of the biggest changes that are taking place in Asia include the decisions } \\
\text { being made by more and more students to leave their country and study abroad. } \\
\text { (Lines 297-300) }\end{array}$ & SVA (event) \\
\hline 8. & $\begin{array}{l}\text { I think that is the major driver of mobility: people's awareness and the people's } \\
\text { initiative.(Lines 300-301) }\end{array}$ & SVC (attribution) \\
\hline 9. & $\begin{array}{l}{[\ldots] \text { 'international higher education has been developing according to business }} \\
\text { models.' (Lines 345-346) }\end{array}$ & SVA (event) \\
\hline
\end{tabular}

Table 3. "Prediction of future situation and suggestions" group. Analysis by type of process.

\begin{tabular}{|l|l|l|}
\hline No. & Statement & Type of process \\
\hline 1. & $\begin{array}{l}\text { Narrowing the gap and minimizing that cause of brain drain will promote greater } \\
\text { and faster regional integration. (Lines 33-35) }\end{array}$ & SVO (action) \\
\hline 2. & $\begin{array}{l}\text { The future movement of people and the movement of intellectuals in this region } \\
\text { will mimic the Bologna or European movement of people [...]. (Lines 43-45) }\end{array}$ & SVO (action) \\
\hline 3. & {$[\ldots]$ Because of the diversity we have to help the poor ones. (Lines 46-47) } & SVO (action) \\
\hline 4. & $\begin{array}{l}\text { But mutual understanding can also be encouraged through such exchanges. (Lines } \\
\text { 61-62) }\end{array}$ & SVC (attribution) \\
\hline 5. & $\begin{array}{l}\text { It is responsibility of the most developed systems to offer more assistance to } \\
\text { developing countries in various ways [...]. (Lines 74-76) }\end{array}$ & SVC (attribution) \\
\hline 6. & $\begin{array}{l}{[\ldots] \text { It was made very clear that the social dimension will always be present and }} \\
\text { all actors (students, faculties, administrators, etc.) are part of the Bologna process } \\
\text { negotiations. (Lines 138-140) }\end{array}$ & $\begin{array}{l}\text { SVC, } \\
\text { (attribution) }\end{array}$ \\
\hline 7. & Most of the European universities will remain public. (Lines 142-143) & SVC (attribution) \\
\hline 8. & $\begin{array}{l}{[\ldots] \text { More mobility will come and the public universities will become more }} \\
\text { nimble [...]. (Lines 143-145) }\end{array}$ & SV(action), SVC \\
\hline 9. & $\begin{array}{l}\text { Instead, an international economics approach must be integrated to make a further } \\
\text { in-depth analysis, so that we can measure the impact and influence on the region } \\
\text { by way of transnational education. (Lines 196-199) }\end{array}$ & $\begin{array}{l}\text { SVC(attribution), SVO } \\
\text { (action) }\end{array}$ \\
\hline
\end{tabular}

nominalization is used (this will be addressed further). In view of the explanation, provided by Fairclough [1], I think that the participants describe the current situation in this way in order to avoid focusing on responsible agents. By contrast, when making statements about future, participants choose to present the processes in form of actions. In my opinion, by doing this they claim their decision to take responsibility for future and recognize their roles as responsible agents in the actions. In my opinion, as

\subsection{Agency}

The speakers did not use many animate agents. We can interpret it as "obfuscation of agency, causality and responsibility" [1, p. 124]. If we look at the list of agents in the statements of the first group "Description of current situation", we will see:

Abstract nouns: the quality of some universities; the European project; the Bologna process; changes; international higher education; the institutional 
initiative; people's awareness and the people's initiative.

Inanimate nouns: European universities; the market.

Nominalizations: the internationalization of higher education.

If we look at the list of agents in the statements of the second group, "Predictions of future situation and suggestion", we will see:

Abstract nouns: social dimension; mobility; an international economics approach; political economic issues; government initiatives; considerations; issues.

Inanimate nouns: European universities; public universities.

Nominalizations: Narrowing the gap; minimizing that cause; movement of people; movement of intellectuals; mutual understanding.

\subsection{Nominalizations}

Using nominalization and process nouns makes responsible agents hidden from us or invisible to us in most processes. To put it simple, we do not know who leads these processes. The only processes, where we know the agents include assistance from developed countries to developing countries, competition between universities and student mobility to some extent. Although, the economic view of student mobility diminishes the role of students as agents, as I mentioned above.

The discussion of participants revolved around 9 main events in the field of higher education: internationalization of higher education; regional integration; assistance (to developing countries by developed countries); student mobility; liberalization; privatization; regional cooperation; regionalism and competition.

In the analyzed text, most of the processes are represented through nominalization and with process nouns.

Internationalization of higher education (lines 12, 21, 27,42 ) is a nominalization. As a result, we do not know who is the agent responsible for the internationalization of higher education - universities, international organizations or anybody else.

Regional integration (lines 26, 33, 35, 319, 308) is a nominalization. The process of regional integration is also described without mentioning the agents, which are taking part or will take part in the process. In my opinion, because integration processes are often represented in society as based on voluntary decisions of countries, mentioning of agents is avoided in order not to create extra pressure on the potential countries - current or future participants in the regional integration.

Assistance to developing countries by developed countries (line 76) - this process is also represented by phrases "to help the development of higher education in developing countries" (lines 39-40) and "to help the poor ones" (line 47). We can see that process noun is used in the first case, and verb clauses are used in the last two cases. By contrast, here the agents are included in sentences, so the reader gets a clear message that it is developed countries, who should help the developing countries. Even in the first sentence with the use of process noun "assistance" developed countries are mentioned. In case of the last sentence, I assume the speaker uses "we" to represent the world community.

Student mobility (lines 67, 144, 300, 304) is also alternatively phrased as:

1. "flow of [..] students" (line 25);

2. "transnational education or student exchange programs" (lines 193-194);

3. "the student market" (lines 218,229);

4. "students who go to northern countries" (line $153)$;

5. "Some of the biggest changes that are taking place in Asia include the decisions being made by more and more students to leave their country and study abroad" (lines 297-300).

Here we can see the use of process noun in 7 cases including the words "flow", "transnational education" and "student market" and the use of verb clause in 2 cases, 1 of which is passive. So, mobility is represented as an independent process, and the use of process nouns and passive voice helps to minimize the role of students as agents who are behind the process of student mobility. Students are presented as agents only in 1 case. This gives us an assumption that student mobility is an independent process, which is more governed by, for example, student market, rather than by students themselves. In my opinion, this demonstrates that participants look at student mobility from the economic point of view.

The process of liberalization is represented by phrases "to liberalize" (lines 142, 257) and "liberalized system" (lines 158-159). Here we can see the use of verb clauses in 2 cases, and passive voice in 1 case. These cases are interesting, because despite the use of verb clauses, the reader does not know the agents of 
liberalization process here. For example, in 1 case with the use of verb clause, the speaker says: "And, even though, there is some homogenization, the Bologna process is not forcing European universities to liberalize." (lines 140-142) The agent responsible (or not responsible) for liberalization here is an inanimate "Bologna process", and no referral to the true agent behind liberalization is made by the speaker. A second case is a phrase "A state could liberalize within Europe [...]" (lines 256-257). In this case, we can see that state is represented as if it can liberalize itself without any external or internal pressure to do it. And again, state is an inanimate object. We do not know specifically the agent responsible for the liberalization of state: a political person or persons, a ministry or any international organization. So, agent behind the process of liberalization is hidden and is invisible to the reader.

The process of privatization is represented in the following statements by the underlined phrases:

1. "That does not mean that European universities are becoming private enterprises - even though some private universities are emerging." (lines 146-148)

2. "But even Vietnam has ambitious plans to expand their private sector to about $30 \%$ $40 \%$ of enrolments by the year 2010." (lines 317-324)

3. "That is the question of the relationship between the public and the private sector in Asia in general, but in Southeast Asia and East Asia in particular. And, how is that changing?" (lines 312-315)

4. "If we look at Southeast Asia for example, in the Philippines, more than $80 \%$ of all enrollments are in the private sector. [...]I don't really see how that would be achieved, but it's indicative of the changing balance between the public and the private sector in Southeast Asia and in East Asia." (lines 317324)

5. “Japan's universities are only privatized to a small degree" (lines 162-163)

Although the word "privatization" is not used here itself, the process of privatization is represented through use of a verb clause in 1 case, process nouns (enrolments, relationship, (changing) balance)) in 3 cases, passive voice in 1 case. In most cases, we do not know who privatizes universities.

As regards to regional cooperation (lines 347, 349, 353,369 ), nominalization is used in all cases - we do not know the agents responsible for regional cooperation. Although I think a reader might assume that this agent is government or governmental structure, I believe that in view of complex structure of modern world, this assumption may be too superficial.

For regionalism (lines 222,247), process noun is used in both cases, and again the agent behind the process of regionalism is hidden from readers.

For competition (line 167), a verb "competing" (line 145 ) is also used. Process noun is used in 1 case and verb clause is used in 1 case. But in both cases, agents are mentioned is sentences: it is public universities and public-led higher education system. In one case, we can see that universities is a more explicit form of representing agents than the phrase "public-led higher education system" (line 166).

\section{CONCLUSION}

Internationalization of higher education was introduced as part of a wider ideology of economic liberalism. This ideology is characterized by advancing privatization at the expense of social dimension [5, p. 274]. Economic liberalism is against the idea that education is "public good" [5, p. 276]. Universities are considered as companies, which shall play by the market rules [5, p. 276]. Economic liberalism supports competition between countries, universities and people [5, p. 275].

From the analysis, we can see the clash of two ideologies "education as private good" and "education as public good". Many participants expressed negative evaluations of liberalism in education, suggesting that more emphasis should be put on cooperation than competition. In this discussion, we can observe a clash between supporters and opponents of liberal education policy.

With issues of inequality between countries, education systems, universities and people, as well as issues of ethnic disagreements threatening the harmony of diversity, the world is perceived by speakers as much more complex than it seems at first.

The combination of formal and informal language allowed participants to have a fruitful discussion on equal grounds. Although the moderator controlled the discussion, he did not attempt to influence the flow of thought.

At the same time, excessive use of nominalization, process nouns and passive voice led to the absence of key agents, who stand behind the ideology of liberalism. In my opinion, this is the main drawback of the discussion, Avoiding to indicate responsible agents allows these "agents" to become invisible and makes 
the ideology of liberalism difficult to oppose. In many cases, the internationalization of higher education is perceived by participants as market-driven and unavoidable.

\section{ACKNOWLEDGMENTS}

The current research is conducted in the frame of the Stipendium Hungaricum program by Tempus Foundation, Hungary. The author would like to thank Professor Gabor Halasz for research supervision during the project and Professor Tanko Gyula for recommendations on Norman Fairclough's approach to $\mathrm{CDA}$.

\section{REFERENCES}

[1] Fairclough, N., Language and power. Pearson Education. 2001.

[2] Fairclough, N., Analysing discourse: Textual analysis for social research. Psychology Press. 2003.

[3] Knight, J., Updating the definition of internationalization. International Higher Education, 33(6),2003, pp. 2-3.

[4] Trends in international higher education and regionalism. Waseda University Global COE Program, Global Institute for Asian Regional Integration. 2009.

[5] Yang, R., Globalisation and higher education development: A critical analysis. International Review of Education, 49(3), 2003. pp 269-291. 